\title{
WHO BEARS THE CORPORATION INCOME TAX?
}

\author{
RIGHARD GOODE†
}

I N RECENT YEARS, more and more of those who have commented on the corporation income tax have disclaimed knowledge of its incidence. Many discussions include a section based on the assumption that the tax remains on corporations and their shareholders and another section founded on the assumption that the tax is fully passed on to consumers in higher prices. This state of uncertainty, I fear, has confused the public and legislators and has allowed everyone to choose his own assumption to fit his predilections or policy program.

While there has never been any consensus about the long-run effects of the corporate tax, most economists used to agree that, generally speaking, it cannot be shifted to consumers in the short run, while the stock of capital remains approximately constant. The recent skepticism about short-run incidence reflects the spread among economists of doubts previously entertained by businessmen. The traditional view has been challenged because of doubts about the validity of the underlying assumptions regarding business behavior and price setting. At the same time, there has been increased willingness to assume that monetary policy 'will not interfere with a general rise in the price level provoked by increases in costs or taxation.

Attempts to resolve the issue by simple empirical investigation have been frustrated by the great complexity of the subject. Two attempts to overcome the difficulties by use of sophisticated econometric methods were reported in 1963. A study by Professors Marian Krzyzaniak and Richard A. Musgrave found the evidence consistent with full shifting, or more than full shifting, of the corporation income tax in the short run. On the other hand, Professor Challis A. Hall, Jr., considered that, on plausible assumptions regarding the nature of technological progress,

† Brookings Institution. Opinions and interpretations are my own and do not necessarily reflect the views of officers or other staff members of the Brookings Institute. I wish to acknowledge helpful comments and suggestions from John A. Brittain, Edward Denison, Gary Fromm, and Richard E. Slitor. Brittain generously made available his worksheets on corporate profits and related data and collaborated with Slitor and me in statistical estimates of factors influencing profits.

Condensed from The Corporation Income Tax: Papers Presented at the Symposiunt on Business TAXATION (Krzyzaniak ed. 1965) by permission of the Wayne State University Press. 
zero shifting was more probable than full shifting. ${ }^{1}$ In this paper I do not propose to review the Hall study, but I shall comment on the Krzyzaniak-Musgrave study since its methodology is more elaborate and its conclusions more novel. Before taking up the Krzyzaniak-Musgrave study, I shall give a brief statement of the assumptions underlying opposing hypotheses with respect to short-run shifting. The paper concludes with some comments on long-run shifting.

\section{SHORT-RUN SHIFTING}

The traditional conclusion that a tax on net profits does not affect prices in the short run rests on a simple proposition. If firms are maximizing their profits before the tax is imposed, or are attempting to do so, the tax gives them no reason to change their prices. Maximum profits will be attained by setting price and output at the point at which the cost of producing and selling a small addition to output equals the additional revenue obtained (when marginal cost equals marginal revenue). The price and output that will yield maximum profits before the tax is levied will yield maximum profits after the tax is in effect; any increase in price by a firm operating at its optimum point will reduce profits before tax and will leave it with smaller after-tax profits than it would obtain at the old price. Certain qualifications of the no-shifting conclusion have usually been conceded but have ordinarily been regarded as fairly minor exceptions to the general rule. ${ }^{2}$

The hypothesis that short-run shifting of a profits tax is general, rather than exceptional, implies that firms usually set prices below the point that would yield maximum profits and that an increase in the tax stimulates them to exercise their unexploited market power. This must be true because if prices, costs, and output had already been in the most-profitable relationship, a price increase intended to recoup the tax would be unsuccessful and indeed would depress profits. The shifting hypothesis, therefore, goes beyond a common criticism of price theory which holds that firms set prices by rule of thumb and try to earn a target rate of return. ${ }^{3}$ Conventional behavior of that kind might

1 Krzyzaniak \& Musgrave, The Shifting of the Corporation Income Tax (1963) [hereinafter cited as K \& M]; Hall, Direct Shifting of the Corporation Income Tax in Manufacturing, 54 An. EcoN. REv. 258 (1964) (Papers and Proceedings). This paper was presented at the December 1963 meeting of the American Economic Association.

$2 \mathrm{~K}$ \& M 1-8; Goode, The Corporation Income TAX 44-54 (1951); Brown, The Corporate Income Tax in the Short Run, 7 NAT'L TAX J. 240-41 (1954).

3 Kaplan, Dirlam \& Lanzillotit, Pricing in Big Business, A Case Approach (1958); Gordon, Short-Period Price Determination in Theory and Practice, 38 AM. Econ. REv. 265 (1948); Lanzillotti, Pricing Objectives in Large Companies, 48 AM. Econ. REv. 921 (1958). 
equally well result in prices higher than those that would yield maximum profits.

According to orthodox theory, there are vital differences between an increase in profits tax rates and increases in excise taxes or wage rates and raw-material prices. Whereas the latter raise marginal variable costs and thus ordinarily push up the equilibrium price, the profits tax does not directly affect the elements that are supposed to enter into the calculation of the optimum price in the short run. Furthermore, the increase in variable costs affects all producers more or less equally whereas the profits tax per unit of output varies widely among producers according to their individual profitability. The usual view has been that highly profitable firms will be deterred from raising prices, in an effort to recoup the corporate tax, by the threat of loss of business to less-profitable competitors. The shifting hypothesis stresses the price-leadership role of large oligopolistic firms.

\section{Krzyzaniak and Musgrave's Econometric Analysis}

Krzyzaniak and Musgrave (hereinafter abbreviated, K \& $M$ ) employ an econometric analysis designed to isolate the influence of the corporation income tax by statistically allowing for nontax factors (or holding constant the nontax factors). Their technique is to attempt to explain short-run changes in the before-tax rate of return on capital in manufacturing corporations by an econometric model that includes the corporate tax as one independent variable.

$\mathrm{K}$ \& M's standard model includes, in addition to the corporate tax, three other variables that are supposed to account for changes in the rate of return on invested capital of manufacturing corporations: (1) the change in the ratio of consumption expenditures to gross national product (GNP); (2) the ratio of inventory to sales for all manufacturing establishments; and (3) the ratio of accruals of all federal, state, and local taxes other than the corporate income tax (minus government transfer payments) to GNP. The first two of these three variables are lagged one year.

$K$ \& $M$ find that the corporate tax was more than 100 per cent shifted in the period 1935-42, 1948-59. Their results for their so-called "standard model" indicate that the degree of shifting was 134 per cent, and many of their other results are close to this figure. ${ }^{4}$ These startling findings imply that the short-run effect of an increase in the corporate tax is to raise after-tax profits rather than to depress them.

I propose to consider the $K \& M$ model from the point of view of its implications concerning the nature of consumer demand and monetary

$4 \mathrm{~K} \& \mathrm{M} 45$. 
conditions, the variables included and excluded, and the plausibility of the estimates of rates of return and tax shifting.

Implications for Demand and Monetary Conditions. $\mathrm{K}$ \& $\mathrm{M}$ 's findings imply that consumers are willing and able to spend more in the aggregate for manufactured goods whenever prices are raised because of an increase in the corporate tax. Furthermore, $K \& M$ do not suggest that additional expenditures for manufactures are offset by reductions in other outlays. Hence, aggregate money expenditures must rise, and it seems that the ratio of consumption expenditures to disposable income of consumers will have to rise, despite a decrease in the real value of cash balances and other fixed claims. The monetary authorities are assumed to allow any expansion that may be needed to support higher prices.

All this seems to imply that-within the broad range of conditions covered by the $\mathrm{K} \& \mathrm{M}$ study-there were virtually no market or monetary limitations on the extent to which firms could raise prices. They could have obtained huge increases in profits, in the absence of any change in taxes, if they had acted in informal concert. Nor do $\mathrm{K} \& \mathrm{M}$ suggest that if corporate tax rates had been raised more or had been increased more quickly, shifting would have been less complete. Prices of manufactured goods appear to rotate on an axis that has no visible connection with a solid base.

Variables. Among the independent variables selected by $\mathrm{K}$ \& $\mathrm{M}$ to explain corporate profits, the ratio of inventory to sales has some appeal, but, on economic grounds, the one-year lag is curious. The relevance of the change in the ratio of consumption to GNP escapes me. A rise in this ratio, for example, might be due to causes as diverse as a reduction in private investment or a cut in personal taxes. Also obscure is the reason why the average effective rate of all taxes other than the federal corporation income tax-measured by the ratio of tax accruals to GNP - should affect profits. Should a high rate for other taxes raise or depress profits? A positive influence might be rationalized on the grounds that rising taxation has accompanied increases of government expenditures, which are expansionary even when financed by taxation. A negative influence might be taken as an indication that, given the level of government expenditures, a tax increase is deflationary. $K \& M$ find the influence to be negative but do not explain why this should be true.

Variables omitted from $\mathrm{K} \& \mathrm{M}$ 's standard model that might be expected to help account for short-run variations in profits include measures of pressure on economic resources, the rate of utilization of manufacturing capacity, the rate of change in manufacturing production or sales, the level and rate of change of government expenditures, and the relation 
between prices and labor costs, as determined by productivity and wage rates.

Although they did not succeed in statistically isolating this effect, $K$ \& $M$ agree that an increase in government expenditures probably is favorable to profits and concede that the rise in the before-tax rate of return on capital "reflects tax shifting in the sense of administered price adjustments, as well as responses to changes in government expenditures." This is a highly important point, especially since the rise in government, expenditures after the mid-1930's was intimately associated with the growth of money income and real output, which was conducive to better profits. $K \& M$, to be sure, argue that the statistical results "suggest" that the tax factor is "much stronger" than the governmentexpenditures ratio as an influence on profits. However, I am most reluctant to rest such a judgment on the statistical evidence presented by the authors.

Plausibility of Estimates. Some information bearing on the plausibility of the $K \& M$ estimates is brought together in Table I. Line 1 shows the actual before-tax rate of return on capital of manufacturing corporations in 1936-1939 and 1955-1957. (The rate of return shown is the percentage ratio of profits plus interest paid to equity plus debt.) Line 2 gives the rate of return as estimated from the $K$ \& $M$ econometric model and indicates that the equation yields a close approximation to the actual figures. ${ }^{6}$

The analytical question is whether the large increase in the average

TABLE I

Before-Tax Rate of Return on Total Capital of Manufacturing Corporations: Actual and Alternative Statistical Estimates, 1936-1939 and 1955-1957a (IN PER CENT)

\begin{tabular}{lcc}
\hline \hline \multicolumn{1}{c}{ DESCRIPIION } & $1936-1939$ & $1955-1957$ \\
\hline 1. Actual & 7.46 & 16.15 \\
$\quad$ Estimated by K \& M econometric modelb & 7.55 & 16.33 \\
2. With actual tax rates & 7.55 & 7.21 \\
3. With constant 1936-1939 tax rates & 16.66 & 16.33 \\
4. With constant 1955-1957 tax rates &
\end{tabular}

a Arithmetic means of annual percentages. Data on rates of return and tax rates are from $K \& M 74$. The before-tax rate of return is the sum of profits and interest paid as a percentage of equity plus debt at the beginning of the year.

b Standard model, "naive least squares" technique, pp. 44-45, as recomputed by Richard E. Slitor and Richard Goode.

$5 \mathrm{~K} \& \mathrm{M} 47$.

$6 \mathrm{~K} \& \mathrm{M}$ consider the particular version of their model that is used in Table I less satisfactory than another version; however, I have chosen the so-called "naive least squares" approach because it is simpler than the preferred instrumental-variable technique. The measures of shifting obtained by the two techniques do not differ much. 
rate of return between 1936-1939 and 1955-1957 was associated with the increase in corporate taxes or with other factors. Lines 3 and 4 of Table I were derived by substituting in the $\mathrm{K} \& \mathrm{M}$ equation two sets of constant tax rates to replace the actual tax rates of the periods under examination. Line 3 shows that, according to the $\mathrm{K} \& \mathrm{M}$ model, the rate of return in 1955-1957 would have been less than half as high as it actually was if corporate tax rates had remained at the 1936-1939 level. Line 4 indicates that the rate of return in 1936-1939 would have been more than twice as high as it was if corporate tax rates in that period had already been at their postwar level. With constant tax rates, the estimated rate of return on capital is roughly the same in the prewar and postwar years. In other words, the $\mathrm{K} \& \mathrm{M}$ statistical analysis implies that the net influence of all the nontax factors, taken together, was approximately the same in 1936-1939 and 1955-1957.

I consider the estimates shown in lines 3 and 4 of Table I implausible. It seems unlikely that, except for differences in corporate tax rates, profits would have been substantially the same in 1936-1939 and in 1955-1957, in view of differences between the two periods with respect to unemployment rates, the apparent intensity of use of plant and equipment, price developments, and other factors that are widely regarded as influencing profits.

The $\mathrm{K} \& \mathrm{M}$ econometric model (preferred version) shows almost the same degree of shifting of the corporate tax as is suggested by simple computations on the basis of changes in the tax rate between 1936-1939 and 1955-1957, without allowance for nontax factors. Thus, for all manufacturing corporations, the percentages of shifting estimated by the two methods are as follows:?

TABLE II

\begin{tabular}{|c|c|c|}
\hline Shifting Mfeasure & CRUDE METHOD & ECONOMETRIC METHOD \\
\hline Equity capital base & 136 & 123 \\
\hline Total capital base & 134 & 134 \\
\hline Equity capital, with & & \\
\hline correction for inflation & 99 & 101 \\
\hline
\end{tabular}

The remarkable correspondence between the estimates derived by the two methods leaves me more worried than reassured.

The fact is, of course, that measured rates of return on corporate capital tended to rise simultaneously with the increase in production, the reduction in idle capacity, the growth of government expenditures,

7 The crude method is a comparison of before-tax rates of return in 1936-1939 with those in 1955-1957; the econometric model is Model A, 1935-1942, 1948-1959. K \& $\mathrm{M} 64$. 
and general inflationary pressures after the mid-1930's. Corporate tax rates also rose during World War II, were cut after the war, were increased during the Korean War, and then were cut again but not to the 1936-1939 level. Except in the years immediately after World War II, the movement of tax rates was roughly coincident with that of forces which would have tended to raise or depress profits in the absence of short-run shifting. The forces that raised profits after 1939 also pushed up wage rates. Perhaps an ingenious person, following the lead of $\mathrm{K} \& \mathrm{M}$, could construct a model that would indicate that the increase in individual income taxes payable by wage earners was fully shifted.

\section{Conclusions with Respect to Short Run}

My conclusion is that the case for short-run shifting of a large fraction of the corporation income tax remains unproved. My own inclination is to continue to employ the working hypothesis that little short-run shifting occurs and that, with a given capital stock, changes in the corporate tax rate affect mainly profits. In brief the $\mathrm{K} \& \mathrm{M}$ statistical analysis does not persuade me that short-run shifting occurs on a large scale. I do not think that $\mathrm{K} \& \mathrm{M}$ have succeeded in isolating the tax variable from the other, and in my judgment more important, factors that influence profits.

My hypothesis is that short-run changes in corporate profits reflect mainly changes in the economic environment, particularly the rate of capacity utilization and the degree of inflationary pressures. The level and rate of change of government expenditures contribute importantly to capacity utilization and inflationary or deflationary pressures and are also associated with statutory and effective corporate tax rates.

\section{Long-Run SHIFTING}

The absence of short-run shifting of the corporate tax would not mean that long-range shifting could not occur. Indeed, the traditional view is that long-run shifting may occur because short-run shifting does not. In the absence of short-run shifting the immediate impact of the tax will tend to reduce rates of return on corporate equity. This may divert capital from corporate equity to other investments, and it may retard total capital formation. Tax shifting will result to the extent that the scarcity of corporate equity capital drives up the before-tax rate of return on it. The degree of shifting will depend, inter alia, on the feasibility of reallocating capital between corporate equity and other investments and the sensitivity of investment as a whole to the rate of return.

Statistics compiled from accounting statements show that the beforetax rate of return on corporate equity capital has been much higher in prosperous years after World War II than in the 1920's, when tax rates 
were lower. For manufacturing corporations, profits rose enough between 1927-1929 and 1955-1957 to allow an increase in the after-tax return, despite much higher tax rates (Table III). These two periods appear to have comprised years of comparable utilization of resources. With the slowing down of activity in 1958-1960, profit rates declined but still remained above the level of the late 1920's.

At face value, the rate-of-return statistics appear to be consistent with a large amount of shifting of the corporate tax. On the other hand, statistics on the profits share of income originating in manufacturing corporations indicate only a small change between 1927-1929 and 1955-1957 (Table III). While these statistics do not necessarily contradict those on the rate of return, they suggest that any tax shifting that occurred took place by economizing on the use of capital rather than through a simple markup of prices or a reduction of wages, which would have increased the profits share in income produced.

There is independent evidence of a long-term decline in the capital intensity of manufacturing, as measured by the ratio of the value of capital to output. This decline began between 1919 and 1929. The capital-output ratio fell from 1.02 in 1919 to 0.88 in 1929 to 0.59 in $1953 . .^{8}$ This change could be partly due to a capital shortage created by high corporate tax rates; however, it is significant that the decline in the ratio began in a period of low taxes. Changes in technology, communications, transportation, and business methods may have played important roles.

Part of the apparent increase in the rate of return on invested capital may be due to the failure of book value to reflect true value in an inflationary period and to changes in depreciation methods and other accounting conventions. Uncertainties are also introduced by the valuation of intangibles and changes in the degree of consolidation of balance sheets and income statements. It is extremely difficult, and perhaps impossible, to correct for all these items. A rough adjustment can be made by relating profits of manufacturing corporations to the value of reproducible tangible capital (structures, equipment, and inventory) of these corporations, with both items valued in constant prices. For this purpose, I used estimates of net capital stocks and profits by the Office of Business Economics of the U.S. Department of Commerce. The capital-stock figures were available in constant 1954 prices and had been derived on the basis of constant depreciation methods. I converted profits to 1954 prices by deflating by an implicit price index for plant and equipment in manufacturing. On this basis, it appears that the before-tax rate of return on reproducible tangible capital increased from 15.2 per cent in 1929 to

8 Measured in constant 1929 prices. See Creamer, Dobrovolsky \& Borenstern, Captral in Manufacturing and Mining: Its formation and Financing 40 (1960). 
18.3 per cent in $1955-1957,,^{\circ}$ which is a much smaller increase than that shown by unadjusted figures such as those included in Table IIII.

TABLE III

Profits in Retation to Book Value of Equity Capital and National Income Produced: Manufacturung Corporations, Selected Years, 1927-1960a (In Per Cent)

\begin{tabular}{lcccc}
\hline \hline ITEM & $1927-1929$ & $1936-1939$ & $1955-1957$ & $1958-1960$ \\
\hline $\begin{array}{l}\text { Return on equityb } \\
\text { Before tax }\end{array}$ & 8.8 & 7.8 & 18.2 & 13.8 \\
$\quad$ After tax & 7.8 & 6.4 & 9.1 & 6.8 \\
$\begin{array}{l}\text { Share in national } \\
\text { income producedc }\end{array} \quad$ & & & \\
$\quad \begin{array}{l}\text { Profits before tax } \\
\text { Gross cash flowd }\end{array}$ & 22.4 & 19.4 & 24.5 & 20.4 \\
Memo: Statutory corporation & 28.9 & 26.0 & 30.1 & 27.0 \\
income tax ratee & 12.2 & 17.0 & 52.0 & 52.0 \\
\hline
\end{tabular}

a Arithmetic means of annual percentages.

b Based on data compiled from federal tax returns. See Internal Revenue Service, U.S. Treasury Dep't, STATISTICS of INCOME, annual volumes for 1927-1929, 1960; for other years, see $K \&$ \& 73. Equity capital is taken as the arithmetic mean of the values for the end of the current year and the end of the preceding year. For 1927-1929, the return on equity capital is represented by compiled net profits; for other years, by net income.

c Percentage of national income originating in manufacturing corporations. Based on estimates of Office of Business Economics, U.S. Department of Commerce, and supplementary estimates.

d Profits before tax plus depreciation allowances.

e Statutory rate of federal corporation income tax applicable to large firms.

The adjusted figures are not intended to eliminate the influence of inflation but to produce a truer picture of actual profits experience, leaving in profits the real gain realized by equity investors in an inflationary period. This real gain is due to the lag of certain contractual costs and to a reduction in the real value of debt and interest payments. One reason for expecting true profit rates to be higher in the mid-1950's than in the late 1920's is that the later period was one of rising prices whereas prices were falling in the 1920's. In 1929, wholesale prices of nonfarm products were 29 per cent lower than they had been ten years earlier; in 1957, they were 32 per cent higher than in 1947.10 These price movements were attributable to broad developments with respect to liquidity, aggregate income, and productive capacity.

Another nontax factor that may have contributed to higher profit rates

9 Derived from OfFice of Business Economics, U.S. DEP'T OF COMMERcE, NATIONAL InCOME (1954); OfFICE OF Business ECONOMICS, U.S. DEP'T OF COMMERGe, U.S. INCOME and OUtput (1958); Office of Business Economics, U.S. Dep'T OF CoMmerce, SuRvey OF CURRENT Business (July 1962); $I d$. (July 1963).

10 Bureau of Labor Statistics index of wholesale prices of all commodities other than farm products and foods. See Bureau of THE CENSUS, U.S. DEP'T OF COMMERcE, Historical Statistics of the United States, Colonial Times to 1957117 (1960). 
in the 1950's than in the 1920's is a change in the composition of physical capital. Whereas structures represented 49 per cent of the total value of reproducible tangible capital in manufacturing in 1928-1929, they accounted for only 31.5 per cent at the end of 1957 (values in constant 1954 prices). ${ }^{11}$ If the typical or required rate of return is higher for structures than for equipment and inventories, the change in the capital mix helps explain the rise in the over-all rate of return. While direct evidence is not available, it seems plausible to suppose that the rate of return on equipment and inventories should be higher than that on buildings because buildings usually have more alternative uses than equipment and can be more easily and cheaply financed by mortgage credit.

While I cannot pretend that these remarks offer a satisfactory explanation of profit behavior, I believe that they suggest reasons for expecting higher rate of return on capital in prosperous years of the 1950's than in the 1920's, regardless of the corporate tax rate.

\section{Conclusions with Respect to Long Run}

I am left uncertain about the degree of long-run shifting of the corporation income tax. On deductive grounds, I believe that the tax causes some reallocation of capital, which tends to cushion its impact on the return on corporate equity while depressing rates of return elsewhere. This is a kind of long-run shifting, but it does not necessarily indicate that capitalists as a group succeed in throwing off the tax. That is a more doubtful proposition. I do not think that either deductive considerations or the available statistics suggest anything close to full shifting in the latter sense. However, so many influences are at work that extreme caution in drawing conclusions is wise.

Perhaps the narrow question of shifting is unanswerable because we cannot conceptually or statistically hold constant all the relevant variables except corporate tax rates. Powerful political forces are at work to raise profits tax rates at the same time that economic conditions are conducive to rising profits. Would anyone contend that corporate tax rates would have risen so sharply in the 1940's except for the war and accompanying conditions that were very favorable to profits? And going a step farther, is it likely that corporate tax rates would have remained at high levels so long if the postwar economic environment had offered no better profit opportunities than those of the late 1930's? At the same time, high tax rates may contribute to conditions that make for high profits because of long-run shifting or because the revenue yield relaxes political restraints on government spending.

11 Office of Business ECONOMIIC, U.S. DEP'T OF COMMERce, U.S. INCOME AND OUTPUT 196 (1958); OfFIce OF BusIness Economics, U.S. Dep'T OF CoMnIERce, SURVEY OF Current Business 26 (July 1962). 